\title{
Integrating Teaching Models to Enhance Efl Students' Interpersonal Communication Skill and Creativity
}

\author{
Nazriani Lubis*, Asnarni Lubis, Rido Imam Ashadi
}

Department of English Education, Faculty of Education and Teacher Training, Universitas Muslim Nusantara Al Washliyah, Indonesia

Corresponding author: Nazriani Lubis, E-mail: nazrianilubis@gmail.com

\section{ARTICLE INFO}

Article history

Received: August 08, 2018

Accepted: October 22, 2018

Published: October 31, 2018

Volume: 6 Issue: 4

Conflicts of interest: None

Funding: None

\begin{abstract}
This research aims to investigate the effectiveness of integrating project-based learning and experiential learning models toward students' interpersonal communication skill and creativity particularly in using English. This research was conducted by applying quantitative research method with factorial design 2X2 ANOVA The subjects were English as a Foreign Language (EFL) students in English Department of Universitas Muslim Nusantara (UMN) Al Washliyah Medan, Indonesia.The instrument was a questionaire with Likert scale and used to measure each formulated indicator. The data were analyzed by using multivariate ANOVA (MANOVA) The finding of the research showed that project-based learning and experiential learning models had a significant effect on students' interpersonal communication skill and creativit. Moreover, interaction was found between communication skill and creativity of students taught by implementing the models. It indicated that ELT classroom activities will be more creative integrating these teaching models. It allows EFL learners to explore knowledge and information independently and to use English as natural as they can either in speaking or writing.
\end{abstract}

Key words: Creativity, ELT Classroom, Interpersonal Communication, Experiential Learning, Project-based Learning

\section{INTRODUCTION}

Interpersonal communication by using English correctly and accurately is one of the major problems faced by English as a Foreign Language (EFL) students in Indonesia. EFL students are expected to have sufficient interpersonal communication skill by using English appropriately since the working life in this globalization age is highly competitive. Yet, based on our observation, most English department students of UMN Al Washliyah face many difficulties and obstcales to communicate with others in English. Some problems include the difficulty in constructing the idea, lacking confidence and creativity as well as lacking interest in practice. This situation is not only caused by the students but also by the implementation of conventional teaching model. Therefore, students do not have many possibilities to gain better English skill. One possible way to change this situation is that EFL lecturers in Indonesia can apply innovative teaching methods by integrating teaching models such as project-based learning and experiential learning model. Such as integrated model is expected not only to improve students' interpersonal communication skill but also to enrich students' creativity for getting involve in any kinds of communication situation, such as, interpersonal communication. According to Pi, Hong Hu (2018), students' creativity can be investigated by peers' ideas and students' openness in group context. Moreover, Gralewski and Karwowski (2018) argued that there are two students' creative styles; adaptors and innovators. Azlina, Amin and Lukito (2018) stated that there are three components of creativity on mathematical-problem solving; flexibilty, novelty and fluency. Then, students' creativity as a result, the creativty of EFL students will have more opportunities to produce creative idea, to speak a specific topic, and to build up the confidence. Maulany (2013) stated that Project-based Learning is an activity of completing the certain problem in certain time arranged comperehensively in order to allow students to explain all the phases, to communicate the process, and to produce a well-arranged project in accordance with the steps planned in advance. In addition, Eskrootchi and Oskrochi (2010) also pointed out that through Project-based learning the students' metacognitive would be productively activated. Tiantong and Siksen (2013) also believes that the students should be involved in any kind of activities individually so the students have opportunity to enrich their own skill that comes along with their own logical idea. Lindawati, and Maftukhin (2013) argued that Project-based learning allows the student to complete the case and involve the students in whole activities. In addition, some studies related to this research have been conducted by some researchers; Kusumawati (2012) found out that project-based learning 
significantly affects to the students' mathematic skilland the students are more active in completing the task. Then, the research by Lindawatia nd Maftukhin (2013) also concluded that project-based learning significantly improves students' creativity in each cycle of physic class. Project-based learning in this sophisticated technology was very appropriate for it did not only offered multiple purposes for students in this $21^{\text {th }}$ century learning era such as; proficient communicator and advanced problem solver but it also comprehensively opened up various activities to exercise students' capacities (Bell, 2010; Hafner \& Miller, 2011; Helle, Tynjälä \& Olkinuora, 2006). In solving the problem, the learning process was being held based on constructivism theory in which students completely constructed their communication skill based on facts, concepts, and principles occured in their own surrondings so that the students were easily able to understand the materials (Cahyo, 2013).

In this research, the project offered is creating a short video which contains inspiring story. The students are asked to compose a comprehensive and persuasive text by using right word choice and accurate English. In order to achieve the outcome, the phases followed by the students are elaboarated in Table 1.

Moreover, experiential learning model is cognitive-based learning stated by Dewey, Lewin and Piaget in which this model allows the students to have learning process through practice, perception, cognitive, and behavior (McCarthy, 2010). Azizi, Susanto and Pambudi (2013) argued that experiential learning model directly invites students to share a certain concept they have in accordance with the materials taught. Furthermore, Mughal and Zafar (2011) stated that experiential learning model allows the students who are in the same class/level/atmosphere to have an opportunity to interact with each other which topics is normally easier to understand. Previous research conducted by Warsito (2015) also concluded that implementing experiential model learning increases both students' achievement and students' mastery on certain learning materials. The implementation of experiential learning absolutely led to the students' higher participation and enjoyment during learning process since all the materials were successfully delivered to the students (Lazar, Moysey, Brame, Coulson, Lee, \& Wagner, 2018). In other words, implementing model of experiential learning will encourage the students to share their own experience during the project completion. Thus, it is expected that the students can speak and communicate well during the process. The experiential learning has seven stages as stated as Table 2 .

Based on the explanation above, the integration of project-based learning and experiential learning models affects the students' interpersonal communication skill and

Table 1. The stages of project-based learning

\begin{tabular}{ll}
\hline Stages & Learning activities \\
\hline $\begin{array}{l}\text { Orientation } \\
\text { Formulating the problems } \\
\text { Creating the idea of video }\end{array}$ & $\begin{array}{l}\text { Lecturer explains and decides the purpose of the project based on the problems identified. } \\
\text { Lecturer gives the students the opportunity to decide the theme } \\
\text { Lecturer explains things the students will undertake such as; deciding the idea of video, composing the } \\
\text { persuasive text. } \\
\text { Collecting the data }\end{array}$ \\
$\begin{array}{l}\text { The students collect the data needed, such as; the object of the video, the persuasive text, and the } \\
\text { lecturer will provide the logbook for evaluating each step undertaken. }\end{array}$ \\
$\begin{array}{l}\text { Lecturer let the students work on the project in two weeks. As long as the process, the lecturer keep } \\
\text { monitoring students' project for several times }\end{array}$ \\
$\begin{array}{l}\text { The students are allowed to show their video in front of classroom } \\
\text { Taking the note }\end{array}$ & $\begin{array}{l}\text { The students formulate the short explanation they have experienced during project making, and then it } \\
\text { will be presented in front of the class. }\end{array}$ \\
\hline
\end{tabular}

Table 2. The Stages of experiential learning

\begin{tabular}{ll}
\hline Stages & Learning activities \\
\hline Orientation & $\begin{array}{l}\text { Lecturers introduces the learning activities and motivates the students to develop the confidence } \\
\text { while sharing the experience } \\
\text { The students will be working in group to share their own project completed with other members } \\
\text { prior to sharing in front of classroom } \\
\text { As long as discussion, the students try to identify, to solve the problems found during } \\
\text { completing the project. } \\
\text { Identifying the problem }\end{array}$ \\
$\begin{array}{l}\text { The students are motivated to keep being active in expressing the idea during the discussion } \\
\text { The students are asked to investigate the mistakes found in others' project such; the steps of }\end{array}$ \\
Active experimentation & $\begin{array}{l}\text { Tesigning the video, the terms of persuasive text, word choice, grammar, and accuracy. } \\
\text { The students are asked to correct the mistakes found by others, and then they clarify it so the } \\
\text { project completion is well done technically. } \\
\text { The students have the opportunity to share their own learning experience in front of classroom } \\
\text { by using English accurately. }\end{array}$ \\
\hline
\end{tabular}


creativity. Majid and Rochman (2014) stated that interpersonal communication is the process which involves two or more people who have an intention to exchange the information and to achieve the purpose of communication. Suhendar, Lasmono and Heryana (2014) argued that during teaching learning process, interpersonal communication may be used to recognize both strengths and weakness, so it becomes a stimulus for creating more conducive teaching learning process. Iriantara and Syaripuddin (2013) also said that the problems occured during studying would be solved easily during the interaction through interpersonal communication. Gaining interpersonal communication is assumed to create more dynamic interaction in English classroom. Therefore, the students can construct their own knowledge, develop the confidence, and share the idea accurately. Both students' interpersonal communication and creativity are expected being better since creativity leads to the flexiblity of students in expressing the idea. Abidin (2016) stated that creativity will run successfuly if the students follow up the indicators, namely; elaborative, original, flexible, fluent, and imaginative. Yet, based on the observation, most English students of UMN Al Washliyah still have insufficient knowledge and skills for developing their interpersonal communication skill and creativity to communicate with others by using English accurately.

\section{Objectives}

This research has two major aims;

1. to enhance students' interpersonal communication skill and creativity through the integration project-based learning and experiential learning model and

2. to investigate the possible interaction between interpersonal communication skilland creativity taught by project-based learning and experiential learning model.

\section{METHOD}

This research was conducted by applying quantitative reaseach method in Universitas Muslim Nusantara (UMN) Al Washliyah Medan. The sample was taken by random purposive sampling in which there were two classes chosen with 40 students each; experimental class I was taught by integrating project-based learning and experiential learning model. Experimental class II was taught by using project-based learning. In this research, there was one independent variable; a new teaching method which integrated project-based learning and experiential learning model, and two dependent variables; interpersonal communication, and creativity (Sugiyono, 2008). The study had a factorial design as seen in Table 3.

Moreover, technique of collecting data for interpersonal communication and creativity was done through a questionnaire with Likert scale. In order to obtain the data of students' creativity, the questionnaire was formulated with 10 items. The questionnaire was administered in both experimental groups. The questionnaire was adopted from the aspects and indicators of creativity based on William scale, while, the questionnaire of interpersonal communication skill was adopted from the indicators of presentation scoring rubric (Abidin, 2016). Moreover, the results of validation of questionnaire showed that the questionnaire of creativity and interpersonal communication skill was valid. The results of validation showed that the item completely met the objectives of learning and measured the indicators achieved by the students. In detail, the table of validity and realibity was visualized in Appendix 1. Furthermore, IBM SPSS for Windows (Version 22) was used in order to analyze the data All the data were tested for normality using Kolmgorov Smirnovand once normality was confirmed one-way ANOVA was run to investigate homogeneity, the data were analyzed by using multivariate multivariate ANOVA (MANOVA).

It was believed that all the data could be obtained by comprehensive teaching plan so that experimental group I would had been treated by implementing teaching model collaboration; project-based learning and experiential-based learning in which the learning objectives were completely achieved based on the stages of project-based learning and experiential-based learning (Rochman \&Majid, 2014), while experimental group II was only treated by project-based learning. The way the researcher designed the teaching plan for both experimental groups was shown in Appendix 2.

\section{RESULTS AND DISCUSSION}

Based on data analysis, it was found that all the data were distributed normally. Moreover, Levene's test of equality of error variances indicated that the assumption of equality of variances was met (Table 4).

Based on data analysis, it was found that the implementaion of project-based learning and experiential learning model significantly affects the students' interpersonal skills. Students taught by using this integrated method had better interpersonal communication skill as shown in Figure1:

Figure 1 clearly visualizes that students' interpersonal communication skill was higher when taught by using both project-based learning and experiential learning model. It coud be seen from the five indicators given in the questionnaire, namely; open, emphathetic, supporting, positive, and fair. The students in experimental class I were more open in

Table 3. Factorical design with true experimental

\begin{tabular}{lll}
\hline $\mathrm{MP} \longrightarrow$ & Teaching models & \\
\hline & $\begin{array}{l}\text { Project-based learning } \\
\text { and experiential } \\
\text { learning models }\end{array}$ & $\begin{array}{l}\text { Project-based } \\
\text { learning } \\
\text { model }\end{array}$ \\
& & \\
$\mathrm{SE}$ & $\mathrm{X} 1 \mathrm{Y}$ & $\mathrm{X} 2 \mathrm{Y}$ \\
Interpersonal skill (Y) & $\mathrm{X} 2 \mathrm{Z}$ \\
Creativity (Z) & $\mathrm{X} 2 \mathrm{Z}$ & \\
\hline
\end{tabular}

Table 4. Test of homogenity (Levene's test of equality of error variances)

\begin{tabular}{lcccc}
\hline & F & df1 & df2 & Sig. \\
\hline Interpersoonal communciation & 3.467 & 1 & 58 & .200 \\
Creativity & 2.978 & 1 & 58 & .102 \\
\hline
\end{tabular}




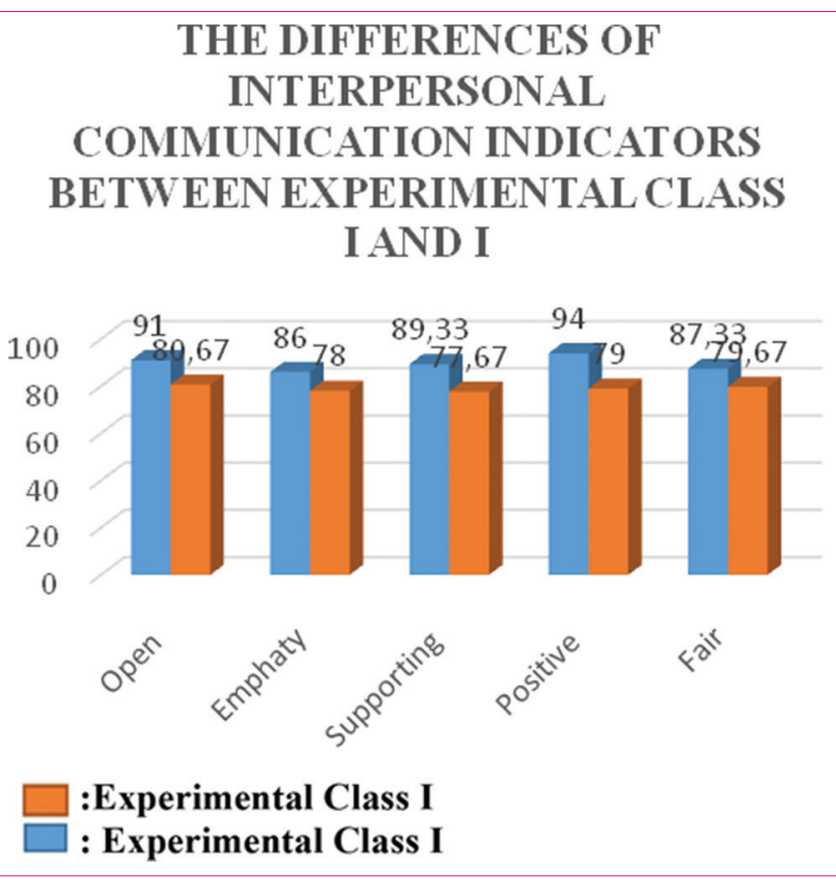

Figure 1. The indicators of interpersonal communication skill

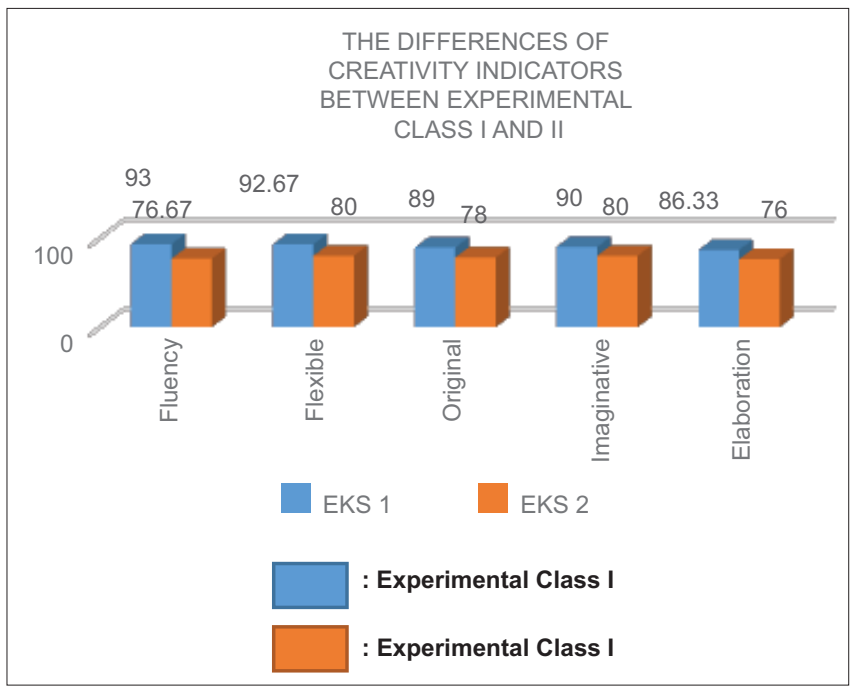

Figure 2. The indicators of students' creativity

communicating with others and scored 91.67while the score of the students when they were taught by project-based learning was only 80.67. Then, for the indicator of emphaty, the students in class experimental I obtained 86 whereas experimental class II was only 76 . The students who were taught by integrating project-based learning and experiential learning model reached 89.3 which was higher than 77.67 for experimental class II.The students in experimental class I were more positive in interpersonal communication skill with 94 which was higher than 79. Finally, the students who were taught by integrating project-based learning and experiential learning model showed fairness during the interaction with score 87.33 while experimental class II was only 79.67 . Furthermore, the the integrated method significantly affectsthe students' creativity as seen in Figure 2.
Figure 2 shows that score of creativity obtained from questionaire formulated for experimental class I and class II was different in terms of all the indicators. The students who were taught by using both project-based learning and experiential learning model were more fluent in improving creativity with the score 93 while class II was only 76.67. The results also showed that class I scored higher (92.67) in flexibility than class II (80). The students in experimental class I were also able to create more original content with 89 while class II scored only 78. Creativity also leads to the level of imagination in order to produce more innovative idea in which class I scored 90, while class II that was taught by implementing project-based learning alone scored only 80 . The indicator of elaboration also showed that class I are was more capable of elaborating the idea with a score of 86.33 while experimental class II scored only 76 . Table 5 presents the inferential statistics results.

The table clearly showed that all variables; interpersonal communication and creativity obtained $p<0.05$. Based on data analysis, integration project-based learning and experiential learning model significantly affects to the students' interpersonal communication skilland creativity. In addition, after analyzing the data, it was found that there was an interaction between interpersonal communication and creativity through implementing the collaboration between project-based learning and experiential learning model as seen in Table 6.

According to the results presented in Table 6, there is an interaction between students' interpersonal communication skill and creativity when taught by a combination of project based learning and experiential learning methods with Sig a significant value of $p=0.0342<05$. Based on the finding, it could be inferred that the innovative teaching learning process designed by the lecturer definitely led to significance of students' interpersonal communication skill and creativity in using English. The students would also get some benefits such as; constructing the original idea creatively, being more confiident, supporting between peers, sharing the experience and being more fair and creative in communicating with others. Considering these benefits, the students would have more opportunity to increase their interpersonal communication skill. They would have to share the topic with others who were very close to their own experience. Obviously, the interaction would be more smoothly and naturally because they communicated based on their own experience especially during the process of completing the project.

The finding of the research was consistent with that of previous research conducted by Azizi, Susanto and Pambudi (2013) which concluded that experiential learning significantly affected the students' achievement. Another study conducted by Maulany (2013) also found that students' speaking skill was higher through implementing project based-learning. Integrating project-based learning and experiential learning model not only improve students' the cognitive skills but also enriched their soft skills. Eskrootchi and Oskkronchi (2010) also pointed out that the teaching learning process would be more active in project-based learning and the students who followed the classoom activities showed better attention and 
Table 5. Tests of between-subjects effects

\begin{tabular}{|c|c|c|c|c|c|c|}
\hline Source & Dependent variable & Type III sum of squares & df & Mean square & $\mathbf{F}$ & $p$ \\
\hline \multirow[t]{2}{*}{ Corrected model } & $\begin{array}{l}\text { Interpersonal } \\
\text { communication }\end{array}$ & $2160.000^{\mathrm{a}}$ & 1 & 2160.000 & 531.448 & 0.000 \\
\hline & Creativity & $2720.267^{b}$ & 1 & 2720.267 & 88.754 & 0.000 \\
\hline \multirow[t]{2}{*}{ Intercept } & $\begin{array}{l}\text { Interpersonal } \\
\text { communication }\end{array}$ & 92512.267 & 1 & 92512.267 & 22761.785 & 0.000 \\
\hline & Creativity & 88320.067 & 1 & 88320.067 & 2881.622 & 0.000 \\
\hline \multirow[t]{2}{*}{ Experimental class } & $\begin{array}{l}\text { Interpersonal } \\
\text { communication }\end{array}$ & 2160.000 & 1 & 2160.000 & 531.448 & 0.000 \\
\hline & Creativity & 2720.267 & 1 & 2720.267 & 88.754 & 0.000 \\
\hline \multirow[t]{2}{*}{ Error } & $\begin{array}{l}\text { Interpersonal } \\
\text { communication }\end{array}$ & 235.733 & 58 & 4.064 & & \\
\hline & Creativity & 1777.667 & 58 & 30.649 & & \\
\hline \multirow[t]{2}{*}{ Total } & $\begin{array}{l}\text { Interpersonal } \\
\text { communication }\end{array}$ & 94908.000 & 60 & & & \\
\hline & Creativity & 92818.000 & 60 & & & \\
\hline \multirow[t]{2}{*}{ Corrected total } & $\begin{array}{l}\text { Interpersonal } \\
\text { communication }\end{array}$ & 2395.733 & 59 & & & \\
\hline & Creativity & 4497.933 & 59 & & & \\
\hline
\end{tabular}

a. $\mathrm{R}$ Squared $=.902$ (Adjusted R Squared $=.900)$, b. R Squared $=.605$ (Adjusted R Squared $=.598)$, c. R Squared $=.811$ (Adjusted R Squared $=.808)$

Table 6. Tests of between-subjects effects

\begin{tabular}{|c|c|c|c|c|c|c|}
\hline Source & Dependent variable & Type III sum of squares & df & Mean square & $\mathbf{F}$ & $p$ \\
\hline \multirow[t]{2}{*}{ Corrected model } & Experimental class & $15.000^{\mathrm{a}}$ & 47 & .319 & . &. \\
\hline & aspek kogniitf & $12862.314^{\mathrm{b}}$ & 47 & 273.666 & 11.231 & 0.000 \\
\hline \multirow[t]{2}{*}{ Intercept } & Experimental class & 128.059 & 1 & 128.059 & . & . \\
\hline & Cognitive skill & 266943.154 & 1 & 266943.154 & 10955.500 & 0.000 \\
\hline \multirow{2}{*}{$\begin{array}{l}\text { Interpersonal } \\
\text { communication }\end{array}$} & Experimental class & 2.083 & 13 & .160 & . & . \\
\hline & Cognitive skill & 1568.273 & 13 & 120.636 & 4.951 & 0.005 \\
\hline \multirow[t]{2}{*}{ Creativity } & Experimental class & .000 & 23 & .000 & . & . \\
\hline & Cognitive skill & 1048.883 & 23 & 45.604 & 1.872 & 0.130 \\
\hline \multirow{2}{*}{$\begin{array}{l}\text { Interpersonal } \\
\text { communication } * \text { creativity }\end{array}$} & Experimental class & .000 & 11 & .000 & . & . \\
\hline & Cognitive skill & 340.595 & 11 & 30.963 & 1.271 & 0.342 \\
\hline \multirow[t]{2}{*}{ Error } & Experimental class & .000 & 12 & 0.000 & & \\
\hline & Cognitive skill & 292.394 & 12 & 24.366 & & \\
\hline \multirow[t]{2}{*}{ Total } & Experimental class & 150.000 & 60 & & & \\
\hline & Cognitive skill & 386563.167 & 60 & & & \\
\hline \multirow[t]{2}{*}{ Corrected total } & Experimental class & 15.000 & 59 & & & \\
\hline & Cognitive skill & 13154.708 & 59 & & & \\
\hline
\end{tabular}

a. R Squared $=1.000$ (Adjusted R Squared $=1.000)$, b. R Squared $=.978($ Adjusted R Squared $=.891)$

interest. This finding also echoes the findings of research conducted by Bell (2010); Hafner and Miller (2011) and Helle, Tynjälä, and Olkinuora (2006) who argued that the implementation of project-based learning certainly met the demands of $21^{\text {st }}$ century as the students' capacities would be exercised with various activities. Moreover, the implementation of project-based learning had been more meaningful to the students since it was collaborated with experiential-based learning in which this research found out that the students significantly achieved both project completiona nd project presentation. As for project presentation, the students were actively engaged and more fluent in promoting their own project. It was similar with the research carried out by Lazar, Moysey, Brame, Coulson, Lee, and Wagner (2018) that focused on breaking out the traditional lecture by applying experiential learning in geogology course. They reported that the students' participation and curiosity were higher. This finding also showed that students' creativity was higher because of the interaction among the 
groups. Pi, Hong and Hu (2018) proved that students' creativity can be investigated by peers' ideas and students' openness in group context. Moreover, the willingness of completing the project showed that students' creativity styles included adaptors and innovators as stated by Gralewski an Karwowski (2018). Then, the video created by the students also showed that flexibity and fluency as two highest indicators achieved by the students in project accompolishment. It was similar with the research by Azlina, Amin, and Lukito (2018) who stated that flexibilty, novelty and fluency were the elements of students' creativity. It can also be interpreted that students who have better interpersonal communication skill would think more creatively. In this research, the students successfully produced a creative short video containing the persuasive text in English.They were also able to share what they had done with their classmates by using English. In short, it was interpreted that the more creative students are, the more convenient they are in communicating with others.

\section{CONCLUSION}

Based on the analysis of the current data, it was concluded that students' interpersonal commmunication skill and creativity were higher when taught by a method which integrated two method than students who were only taught by project-based learning. It was found that the students had more opportunities to complete a creative project with guidance from lecturers. There was an interaction between students' interpersonal communication skill and creativity. In conclusion, the integration of teaching models offers multiple significant benefits especially in studying English as students' will be more productive and communicative.

\section{ACKNOWLEDGMENT}

The authors would like to express sincere gratitude to The Ministry of Research, Technology, \& Higher Education of the Republic of Indonesia for the financial support.

\section{REFERENCES}

Abidin, Y. (2016). Revitalisasi Penilaian Pembelajaran dalam Konteks Pendidikan Multiliterasi Abad Ke21. Bandung: PT Refika Aditama.

Azlina, N., Amin, S. M., \& Lukito, A. (2018). Creativity of Field-dependent and Field-independent Students in Posing Mathematical Problems. In Journal of Physics: Conference Series, 947(1). IOP Publishing.

Azizi, A., Susanto, S., \& Pambudi, D. S. (2013). Penerapan Model Experiential Learning Untuk Meningkatkan Hasil Belajar Pokok Bahasan Unsur Lingkaran Siswa Kelas VIII SMP Salafiyah Miftahul Huda Jenggawah Tahun Ajaran 2012/2013. KadikmA, 4(3).

Bell, S. (2010). Project-based learning for the $21^{\text {st }}$ century: Skills for the future. The Clearing House, 83(2), 39-43.

Cahyo, A. N. (2013). Panduan aplikasi teori-teori belajar mengajar teraktual dan terpopuler.

Eskrootchi, R., \& Oskrochi, G. R. (2010). A study of the efficacy of project-based learning integrated with comput- er-based simulation-STELLA. Educational Technology \& Society, 13(1), 236-245.

Gralewski, J., \& Karwowski, M. (2018). Are teachers' implicit theories of creativity related to the recognition of their students' creativity?. The Journal of Creative Behavior, 52(2), 156-167.

Hafner, C. A., \& Miller, L. (2011). Fostering learner autonomy in English for science: A collaborative digital video project in a technological learning environment.

Helle, L., Tynjälä, P., \& Olkinuora, E. (2006). Project-based learning in post-secondary education-theory, practice and rubber sling shots. Higher Education, 51(2), 287-314.

Iriantara, Y., \& Syaripuddin, U. (2013). Komunikasi Pendidikan. Simbiosa Rekatama Media

Kusumawati, N. (2012). Pengembangan Perangkat Pembelajaran Matematika Model Project Based Learning (PBL) Untuk Meningkatkan Kemampuan Komunikasi Matematik. Pena Jurnal Ilmu Pengetahuan Dan Teknologi, 23(1).

Lazar, K. B., Moysey, S. M., Brame, S., Coulson, A. B., Lee, C. M., \& Wagner, J. R. (2018). Breaking out of the traditional lecture hall: Geocaching as a tool for experiential learning in large geology service courses. Journal of Geoscience Education, 1-16.

Lindawati, S. D. F., \& Maftukhin, A. (2013). Penerapan Model Pembelajaran Project Based Learning untuk Meningkatkan Kreativitas Siswa MAN I Kebumen. Jurnal Radiasi, 3(1), 42-45.Majid., A dan C.Rochman. 2014. Pendekatan Ilmiah Dalam Implementasi Kurikulum 2013. Editor Engkus Kuswandi. Cetakan Pertama. PT Remaja Rosdakarya. Jakarta

Maulany, D. B. (2013). The Use of Project-based Learning in Improving the StudentsSpeaking Skill (a Classroom Action Research at One of Primary Schools in Bandung). Journal of English and Education, 1(1), 30-42.

McCarthy, M. (2010). Experiential learning theory: From theory to practice. Journal of Business \& Economics Research, 8(5), 131-139.

Mughal, F., \& Zafar, A. (2011). Experiential learning from a constructivist perspective: Reconceptualizing the Kolbian cycle. International Journal of Learning and Development, 1(2), 27-37.

Pi, Z., Hong, J., \& Hu, W. (2018). Interaction of the originality of peers' ideas and students' openness to experience in predicting creativity in online collaborative groups. British Journal of Educational Technology.

Rochman, C., \& Majid, A. (2014). Pendekatan Ilmiah dalam Implementasi Kurikulum 2013. Bandung: Rosda karya.

Suhendar, N., Lasmono, D., \& Heryana, N. Peningkatan Keterampilan Komunikasi Interpersonal Guru Bahasa Indonesia Kepada Siswa Menggunakan Metode Problem Solving di Man 2. Jurnal Pendidikan dan Pembelajaran, 3(9).

Sugiyono. (2008). Metode penelitian pendidikan:(pendekatan kuantitatif, kualitatif dan $R \& D)$. Alfabeta. 
Tiantong, M., \& Siksen, S. (2013). The online project-based learning model based on student's multiple intelligence. International Journal of Humanities and Social Science, 3(7), 204-211.
Warsito, V. (2015). Penerapan Model Experiental Learning untuk Meningkatkan Hasil Belajar IPA Fisika Siswa Kelas VII SMP Negeri 5 Palu. Jurnal Pendidikan Fisika Tadulako Online (JPFT), 3(1).

\section{APPENDIX 1}

Validity and reliability results of creativity and interpersonal communication skill questionnaires

The validity of interpersonal communication skill questionnaire

\begin{tabular}{|c|c|c|c|c|c|c|c|c|c|c|c|}
\hline \multirow{3}{*}{$\begin{array}{l}\text { Cronbach's Alpha } \\
0.579\end{array}$} & \multicolumn{11}{|c|}{ Reliability Statistics of Communication Interpersonal } \\
\hline & \multicolumn{11}{|c|}{$\mathrm{N}$ of Items } \\
\hline & Item 1 & Item 2 & Item 3 & Item 4 & Item 5 & Item 6 & Item 7 & Item 8 & Item 9 & Item 10 & Skor total \\
\hline \multicolumn{12}{|l|}{ Item 1} \\
\hline Pearson correlation & 1 & $0.402 *$ & -0.037 & 0.000 & 0.000 & -0.041 & -0.246 & 0.207 & 0.054 & -0.329 & $0.355^{*}$ \\
\hline Sig. (2-tailed) & & 0.028 & 0.848 & 1.000 & 1.000 & 0.830 & 0.190 & 0.273 & 0.776 & 0.076 & 0.024 \\
\hline $\mathrm{N}$ & 30 & 30 & 30 & 30 & 30 & 30 & 30 & 30 & 30 & 30 & 30 \\
\hline \multicolumn{12}{|l|}{ Item 2} \\
\hline Pearson correlation & $-0.402 *$ & 1 & $0.387^{*}$ & -0.171 & 0.259 & 0.158 & 0.141 & -0.063 & -0.192 & -0.104 & $0.387^{*}$ \\
\hline Sig. (2-tailed) & 0.028 & & 0.035 & 0.366 & 0.167 & 0.404 & 0.459 & 0.743 & 0.310 & 0.583 & 0.034 \\
\hline $\mathrm{N}$ & 30 & 30 & 30 & 30 & 30 & 30 & 30 & 30 & 30 & 30 & 30 \\
\hline \multicolumn{12}{|l|}{ Item 3} \\
\hline Pearson correlation & -0.037 & $0.387^{*}$ & 1 & 0.114 & 0.187 & 0.089 & $0.389^{*}$ & 0.146 & -0.283 & -0.166 & $0.600 * *$ \\
\hline Sig. (2-tailed) & 0.848 & 0.035 & & 0.549 & 0.323 & .638 & 0.034 & 0.442 & 0.130 & 0.382 & 0.000 \\
\hline $\mathrm{N}$ & 30 & 30 & 30 & 30 & 30 & 30 & 30 & 30 & 30 & 30 & 30 \\
\hline \multicolumn{12}{|l|}{ Item 4} \\
\hline Pearson correlation & 0.000 & -0.171 & 0.114 & 1 & 0.045 & .234 & 0.102 & -0.172 & 0.226 & -0.076 & $0.390 *$ \\
\hline Sig. (2-tailed) & 1.000 & 0.366 & 0.549 & & 0.815 & 0.213 & 0.590 & 0.363 & 0.230 & 0.690 & 0.020 \\
\hline $\mathrm{N}$ & 30 & 30 & 30 & 30 & 30 & 30 & 30 & 30 & 30 & 30 & 30 \\
\hline \multicolumn{12}{|l|}{ Item 5} \\
\hline Pearson correlation & 0.000 & 0.259 & 0.187 & 0.045 & 1 & -0.059 & 0.103 & 0.016 & -0.200 & 0.115 & $0.467 * *$ \\
\hline Sig. (2-tailed) & 10.000 & 0.167 & 0.323 & 0.815 & & 0.756 & 0.587 & 0.932 & 0.290 & 0.545 & 0.009 \\
\hline $\mathrm{N}$ & 30 & 30 & 30 & 30 & 30 & 30 & 30 & 30 & 30 & 30 & 30 \\
\hline \multicolumn{12}{|l|}{ Item 6} \\
\hline Pearson correlation & -0.041 & .158 & 0.089 & 0.234 & -0.059 & 1 & -0.244 & 0.008 & 0.024 & -0.186 & $0.399^{*}$ \\
\hline Sig. (2-tailed) & 0.830 & 0.404 & 0.638 & 0.213 & 0.756 & & 0.193 & 0.967 & 0.900 & 0.326 & 0.018 \\
\hline $\mathrm{N}$ & 30 & 30 & 30 & 30 & 30 & 30 & 30 & 30 & 30 & 30 & 30 \\
\hline \multicolumn{12}{|l|}{ Item 7} \\
\hline Pearson Correlation & -0.246 & 0.141 & $0.389 *$ & 0.102 & 0.103 & -0.244 & 1 & -0.009 & 0.053 & 0.306 & $0.463 * *$ \\
\hline Sig. (2-tailed) & 0.190 & 0.459 & 0.034 & 0.590 & 0.587 & 0.193 & & 0.961 & 0.780 & 0.100 & 0.010 \\
\hline $\mathrm{N}$ & 30 & 30 & 30 & 30 & 30 & 30 & 30 & 30 & 30 & 30 & 30 \\
\hline \multicolumn{12}{|l|}{ Item 8} \\
\hline Pearson correlation & 0.207 & -0.063 & 0.146 & -0.172 & 0.016 & 0.008 & -0.009 & 1 & 0.031 & 0.076 & $0.395^{*}$ \\
\hline Sig. (2-tailed) & 0.273 & 0.743 & 0.442 & 0.363 & 0.932 & 0.967 & 0.961 & & 0.871 & 0.688 & 0.031 \\
\hline $\mathrm{N}$ & 30 & 30 & 30 & 30 & 30 & 30 & 30 & 30 & 30 & 30 & 30 \\
\hline \multicolumn{12}{|l|}{ Item 9} \\
\hline Pearson correlation & 0.054 & -0.192 & -0.283 & 0.226 & -0.200 & 0.024 & 0.053 & 0.031 & 1 & 0.082 & $0.375^{*}$ \\
\hline Sig. (2-tailed) & 0.776 & 0.310 & 0.130 & 0.230 & 0.290 & 0.900 & 0.780 & 0.871 & & 0.666 & 0.017 \\
\hline $\mathrm{N}$ & 30 & 30 & 30 & 30 & 30 & 30 & 30 & 30 & 30 & 30 & 30 \\
\hline Item 10 & & & & & & & & & & & \\
\hline
\end{tabular}


The validity of interpersonal communication skill questionnaire

\begin{tabular}{|c|c|c|c|c|c|c|c|c|c|c|c|}
\hline \multirow{3}{*}{$\begin{array}{l}\text { Cronbach's Alpha } \\
0.579\end{array}$} & \multicolumn{11}{|c|}{ Reliability Statistics of Communication Interpersonal } \\
\hline & \multicolumn{11}{|c|}{$\mathrm{N}$ of Items } \\
\hline & Item 1 & Item 2 & Item 3 & Item 4 & Item 5 & Item 6 & Item 7 & Item 8 & Item 9 & Item 10 & Skor total \\
\hline Pearson correlation & -0.329 & -0.104 & -0.166 & -0.076 & 0.115 & -0.186 & 0.306 & 0.076 & 0.082 & 1 & $0.378^{*}$ \\
\hline Sig. (2-tailed) & 0.076 & 0.583 & 0.382 & 0.690 & 0.545 & 0.326 & 0.100 & 0.688 & 0.666 & & 0.025 \\
\hline $\mathrm{N}$ & 30 & 30 & 30 & 30 & 30 & 30 & 30 & 30 & 30 & 30 & 30 \\
\hline \multicolumn{12}{|l|}{ Skor Total } \\
\hline Pearson correlation & $0.355^{*}$ & $0.387^{*}$ & $0.600 * *$ & $0.390^{*}$ & $0.467 * *$ & $0.399 *$ & $0.463 * *$ & $0.395^{*}$ & $0.375^{*}$ & $0.378^{*}$ & 1 \\
\hline Sig. (2-tailed) & 0.024 & 0.034 & 0.000 & 0.020 & 0.009 & 0.018 & 0.010 & 0.031 & 0.017 & 0.025 & \\
\hline $\mathrm{N}$ & 30 & 30 & 30 & 30 & 30 & 30 & 30 & 30 & 30 & 30 & 30 \\
\hline
\end{tabular}

*. Correlation is significant at the 0.05 level (2-tailed), **. Correlation is significant at the 0.01 level (2-tailed).

AQ1 The validity of creativity questionnaire

\begin{tabular}{|c|c|c|c|c|c|c|c|c|c|c|c|}
\hline \multirow{3}{*}{$\begin{array}{l}\text { Cronbach's Alpha } \\
0.528\end{array}$} & \multicolumn{11}{|c|}{ Reliability Statistics of Creavitity Questionnaire } \\
\hline & \multicolumn{11}{|c|}{ N of Items } \\
\hline & Item 1 & Item 2 & Item 3 & Item 4 & Item 5 & Item 6 & Item 7 & Item 8 & Item 9 & Item 10 & Skor total \\
\hline \multicolumn{12}{|l|}{ Item 1} \\
\hline Pearson correlation & 1 & -0.218 & -0.124 & -0.307 & -0.117 & $0.447 *$ & -0.310 & 0.222 & 0.022 & $-0.548 * *$ & $0.362 *$ \\
\hline Sig. (2-tailed) & & 0.247 & 0.515 & 0.099 & 0.538 & 0.013 & 0.096 & 0.238 & 0.907 & 0.002 & 0.028 \\
\hline $\mathrm{N}$ & 30 & 30 & 30 & 30 & 30 & 30 & 30 & 30 & 30 & 30 & 30 \\
\hline \multicolumn{12}{|l|}{ Item 2} \\
\hline Pearson correlation & -0.218 & 1 & -0.142 & -0.045 & 0.204 & 0.000 & 0.073 & -0.302 & 0.136 & 0.073 & $0.372 *$ \\
\hline Sig. (2-tailed) & 0.247 & & 0.455 & 0.815 & 0.279 & 1.000 & 0.702 & 0.105 & 0.473 & 0.702 & 0.040 \\
\hline $\mathrm{N}$ & 30 & 30 & 30 & 30 & 30 & 30 & 30 & 30 & 30 & 30 & 30 \\
\hline \multicolumn{12}{|l|}{ Item 3} \\
\hline Pearson correlation & -0.124 & -0.142 & 1 & 0.259 & 0.159 & -0.178 & 0.237 & -0.185 & -0.154 & 0.031 & $0.424 *$ \\
\hline Sig. (2-tailed) & 0.515 & 0.455 & & 0.166 & 0.401 & 0.346 & 0.208 & 0.328 & 0.416 & 0.871 & 0.020 \\
\hline $\mathrm{N}$ & 30 & 30 & 30 & 30 & 30 & 30 & 30 & 30 & 30 & 30 & 30 \\
\hline \multicolumn{12}{|l|}{ Item 4} \\
\hline Pearson correlation & -0.307 & -0.045 & 0.259 & 1 & 0.233 & -0.192 & $0.400^{*}$ & -0.182 & 0.073 & -0.185 & $0.479 * *$ \\
\hline Sig. (2-tailed) & 0.099 & 0.815 & 0.166 & & 0.216 & 0.310 & 0.029 & 0.336 & 0.702 & 0.327 & 0.007 \\
\hline $\mathrm{N}$ & 30 & 30 & 30 & 30 & 30 & 30 & 30 & 30 & 30 & 30 & 30 \\
\hline \multicolumn{12}{|l|}{ Item 5} \\
\hline Pearson correlation & -0.117 & 0.204 & 0.159 & 0.233 & 1 & 0.159 & 0.356 & -0.185 & 0.167 & -0.089 & $0.680 * *$ \\
\hline Sig. (2-tailed) & 0.538 & 0.279 & 0.401 & 0.216 & & 0.400 & 0.053 & 0.329 & 0.379 & 0.640 & 0.000 \\
\hline $\mathrm{N}$ & 30 & 30 & 30 & 30 & 30 & 30 & 30 & 30 & 30 & 30 & 30 \\
\hline \multicolumn{12}{|l|}{ Item 6} \\
\hline Pearson correlation & $0.447 *$ & 0.000 & -0.178 & -0.192 & 0.159 & 1 & -0.227 & 0.216 & 0.159 & -0.227 & $0.369^{*}$ \\
\hline Sig. (2-tailed) & 0.013 & 1.000 & 0.346 & 0.310 & 0.400 & & 0.227 & 0.252 & 0.400 & 0.227 & 0.047 \\
\hline $\mathrm{N}$ & 30 & 30 & 30 & 30 & 30 & 30 & 30 & 30 & 30 & 30 & 30 \\
\hline \multicolumn{12}{|l|}{ Item 7} \\
\hline Pearson correlation & -0.310 & 0.073 & 0.237 & $0.400 *$ & .356 & -0.227 & 1 & -0.230 & 0.208 & 0.048 & $0.526^{* *}$ \\
\hline Sig. (2-tailed) & 0.096 & 0.702 & 0.208 & 0.029 & 0.053 & 0.227 & & 0.221 & 0.270 & 0.803 & 0.003 \\
\hline $\mathrm{N}$ & 30 & 30 & 30 & 30 & 30 & 30 & 30 & 30 & 30 & 30 & 30 \\
\hline \multicolumn{12}{|l|}{ Item 8} \\
\hline Pearson correlation & 0.222 & -0.302 & -0.185 & -0.182 & -0.185 & 0.216 & -0.230 & 1 & -0.185 & -0.066 & $0.374 *$ \\
\hline Sig. (2-tailed) & 0.238 & 0.105 & 0.328 & 0.336 & 0.329 & 0.252 & 0.221 & & 0.329 & 0.730 & 0.019 \\
\hline
\end{tabular}


Thevalidity of creativity questionnaire (Contiuned)

\begin{tabular}{|c|c|c|c|c|c|c|c|c|c|c|c|}
\hline \multirow{3}{*}{$\begin{array}{l}\text { Cronbach's Alpha } \\
0.528\end{array}$} & \multicolumn{11}{|c|}{ Reliability Statistics of Creavitity Questionnaire } \\
\hline & \multicolumn{11}{|c|}{ N of Items } \\
\hline & Item 1 & Item 2 & Item 3 & Item 4 & Item 5 & Item 6 & Item 7 & Item 8 & Item 9 & Item 10 & Skor total \\
\hline $\mathrm{N}$ & 30 & 30 & 30 & 30 & 30 & 30 & 30 & 30 & 30 & 30 & 30 \\
\hline \multicolumn{12}{|l|}{ Item 9} \\
\hline Pearson correlation & 0.022 & 0.136 & -0.154 & 0.073 & 0.167 & 0.159 & 0.208 & -0.185 & 1 & -0.238 & $0.365^{*}$ \\
\hline Sig. (2-tailed) & 0.907 & 0.473 & 0.416 & 0.702 & 0.379 & 0.400 & 0.270 & 0.329 & & 0.206 & 0.045 \\
\hline $\mathrm{N}$ & 30 & 30 & 30 & 30 & 30 & 30 & 30 & 30 & 30 & 30 & 30 \\
\hline \multicolumn{12}{|l|}{ Item 10} \\
\hline Pearson correlation & $-0.548 * *$ & 0.073 & 0.031 & -0.185 & -0.089 & -0.227 & 0.048 & -0.066 & -0.238 & 1 & $0.377^{*}$ \\
\hline Sig. (2-tailed) & 0.002 & 0.702 & 0.871 & 0.327 & 0.640 & 0.227 & 0.803 & 0.730 & 0.206 & & 0.037 \\
\hline $\mathrm{N}$ & 30 & 30 & 30 & 30 & 30 & 30 & 30 & 30 & 30 & 30 & 30 \\
\hline \multicolumn{12}{|l|}{ Skor total } \\
\hline Pearson correlation & $0.362 *$ & $0.372 *$ & $0.424 *$ & $0.479 * *$ & $0.680 * *$ & $0.369^{*}$ & $0.526 * *$ & $0.374 *$ & $0.365^{*}$ & $0.377^{*}$ & 1 \\
\hline Sig. (2-tailed) & 0.028 & 0.040 & 0.020 & 0.007 & 0.000 & 0.047 & 0.003 & 0.019 & 0.045 & 0.037 & \\
\hline $\mathrm{N}$ & 30 & 30 & 30 & 30 & 30 & 30 & 30 & 30 & 30 & 30 & 30 \\
\hline
\end{tabular}

*. Correlation is significant at the 0.05 level (2-tailed), **. Correlation is significant at the 0.01 level (2-tailed).

\section{APPENDIX 2}

The Example of Teaching Plan of Experimental Group I

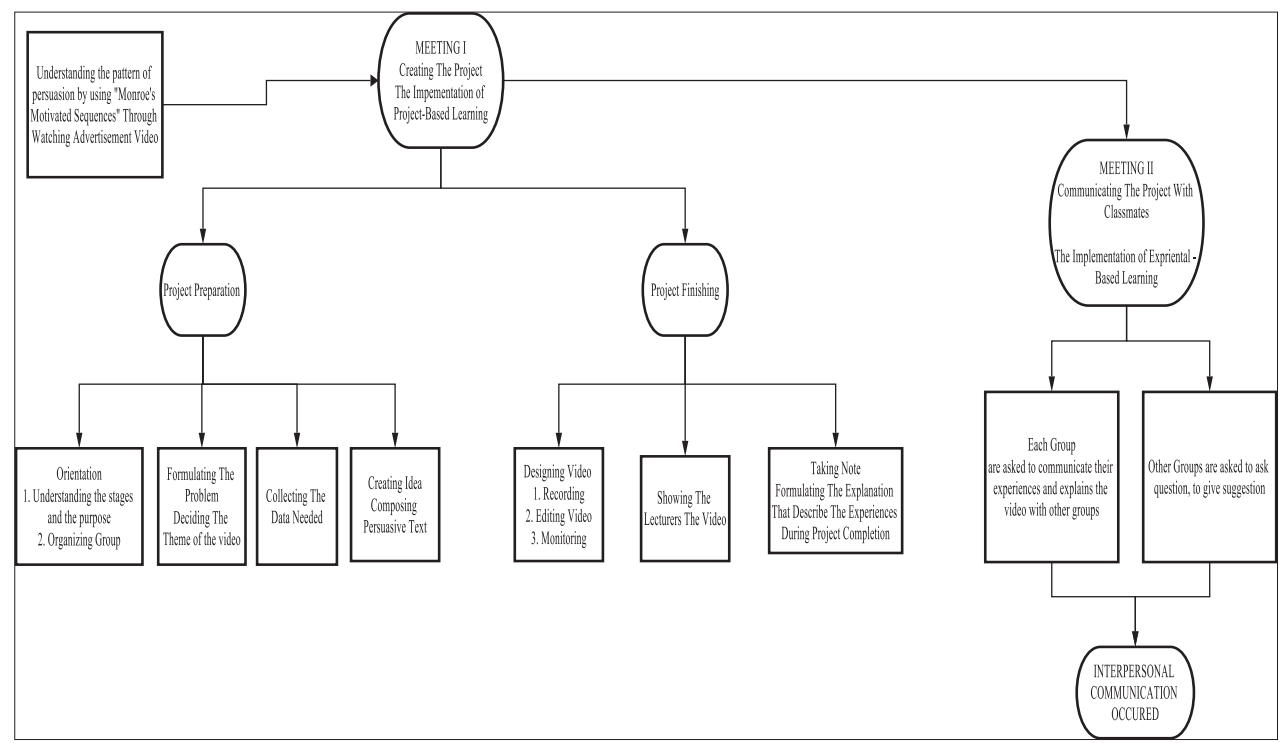

The Example of Teaching Plan of Experimental Group II

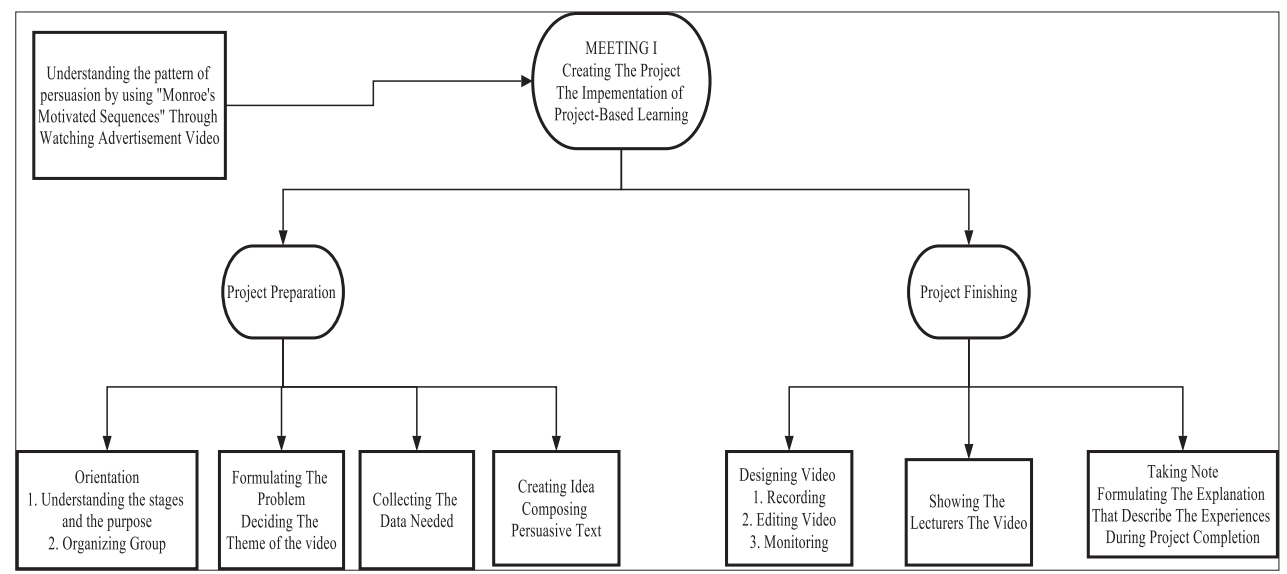

